\title{
A new kinorhynch genus, Mixtophyes (Kinorhyncha: Homalorhagida), from the Guinea Basin deep-sea, with new data on the family Neocentrophyidae
}

\author{
Nuria Sánchez • Fernando Pardos • Martin V. Sørensen
}

Received: 3 October 2013/Revised: 22 January 2014/ Accepted: 28 January 2014/Published online: 9 February 2014

(C) Springer-Verlag Berlin Heidelberg and AWI 2014

\begin{abstract}
A new homalorhagid genus and species, Mixtophyes abyssalis gen. et sp. nov., is described from the deep-sea of the Guinea Basin in the Atlantic Ocean. The new genus and species was collected during the $\mathrm{R} / \mathrm{V}$ Meteor Diva2 M63/2 Cruise, and it is characterized by a trunk with segment 1 consisting of a tergal and a single sternal plate, without any subdivisions or differentiations, segment $2-10$ of one tergal and two sternal plates and segment 11 of a tergal and a sternal plate. Lateral terminal spines are present in both sexes. As part of the study of the new taxon, the type material of Neocentrophyes intermedius and $N$. satyai was re-examined, and new information is provided for both species. Based on the information from Mixtophyes abyssalis gen. et sp. nov. and re-examination of the two Neocentrophyes species, emended diagnoses for Neocentrophyes and Neocentrophyidae are proposed, and an updated identification key to homalorhagid genera and species of Neocentrophyidae is provided. Mixtophyes abyssalis gen. et sp. nov. is tentatively assigned to Neocentrophyidae, but evaluation of our current hypotheses about homalorhagid evolution and phylogeny also
\end{abstract}

Communicated by H.-D. Franke.

N. Sánchez $(\bowtie) \cdot$ F. Pardos

Department of Zoology and Anthropology

(Invertebrate Zoology), Faculty of Biological Sciences,

Universidad Complutense de Madrid, José Antonio Novais 2,

28040 Madrid, Spain

e-mail: nurisanc@bio.ucm.es

M. V. Sørensen

Natural History Museum of Denmark,

University of Copenhagen, Øster Voldgade 5-7,

1350 Copenhagen, Denmark indicated that the family most probably is paraphyletic and that revision of homalorhagid classification is required when new results from phylogenetic analyses become available.

Keywords Diva2 - Meiofauna - Mixtophyes abyssalis gen. et sp. nov. · Neocentrophyes · Taxonomy

\section{Introduction}

Kinorhyncha is a relatively small phylum of meiobenthic invertebrates, with only around two hundred described species (Sørensen 2013). The known species are accommodated in 22 genera which are assigned to two orders, Homalorhagida and Cyclorhagida. According to traditional classification, e.g., Higgins (1990) and Adrianov and Malakhov (1994), the genera are, however, far from been evenly distributed on the two orders. In fact, only four genera, Kinorhynchus, Neocentrophyes, Paracentrophyes and Pycnophyes, are assigned to Homalorhagida, whereas the remaining generic diversity belongs to Cyclorhagida. Recent phylogenetic analyses, based on molecular sequence data, indicate though that at least two or three additional genera are more closely related to the homalorhagids (Dal Zotto et al. 2013; Yamasaki et al. 2013), but still a vast majority of the generic and specific diversity is found among the cyclorhagids. Furthermore, among the seven most recently described genera, six of them are clearly cyclorhagids (Neuhaus and Blasche 2006; Sørensen et al. 2007; Sørensen 2008; Sørensen and Rho 2009; Sørensen and Thormar 2010; Herranz et al. 2012), whereas only one, Franciscideres, might be a homalorhagid even though its morphology differs considerably from the four currently accepted homalorhagid genera (Dal Zotto et al. 2013). 
Hence, discoveries of new homalorhagid genera are rare, and the last description of a certain homalorhagid genus dates more than 30 years from present (Higgins 1983). In the present study, we describe a new kinorhynch species whose general morphology allows an affiliation to Homalorhagida, even though differing from the four known genera, and hence requiring the erection of a new genus. The new species was found at $5,174 \mathrm{~m}$ depth in the Guinea Basin (Atlantic Ocean), which also makes it the deepest recorded kinorhynch species that has been named and described. For comparisons, specimens of Neocentrophyes intermedius Higgins, 1969 and $N$. satyai Higgins, 1969 were re-examined, and new data for these two species are provided.

\section{Materials and methods}

Three specimens of the new kinorhynch genus and species were found in samples collected during the R/V Meteor DIVA2 M63/2 Cruise that lasted from February to the end of March 2005 and collected Mid-Atlantic deep-sea samples from the Northeastern Cape Basin west of South Africa and Angola, in the Northwestern Angola Basin off Angola's coasts, and from several areas in the Guinea Basin, south of the Ivory Coast and Ghana (Fig. 1) (see also Türkay 2005). In all three Basins, the depths exceed 5,000 m.

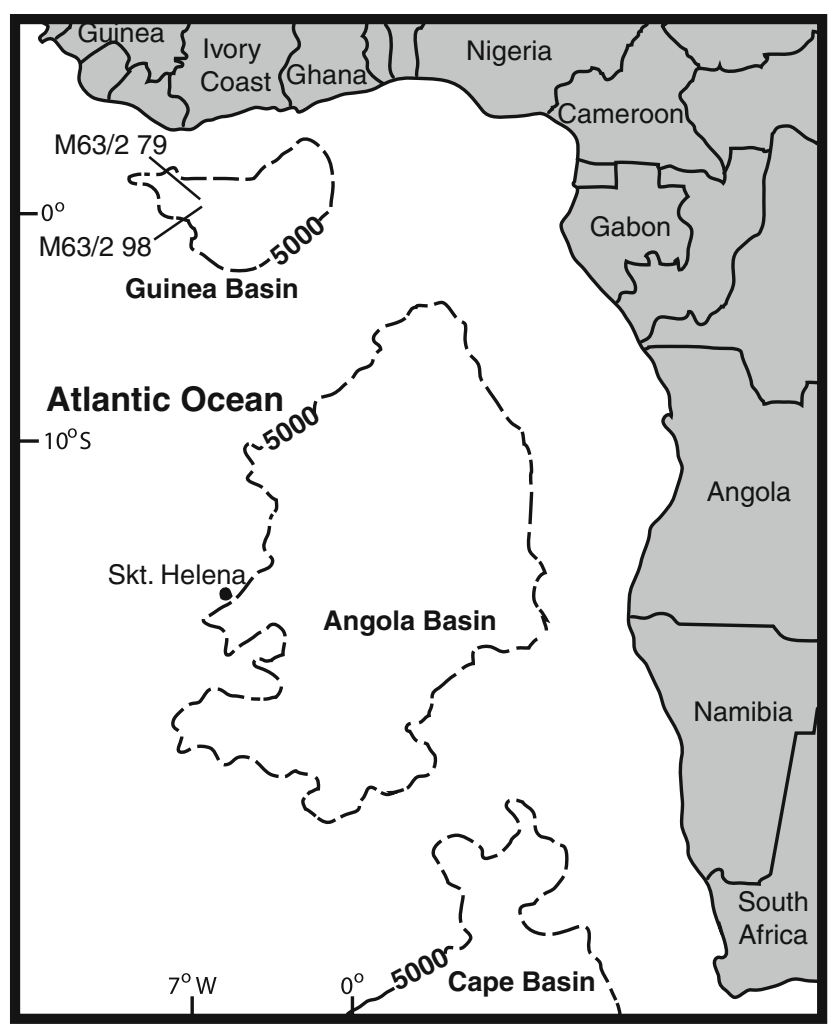

Fig. 1 Map showing the sampling areas of R/V Meteor and the two sampling localities, M63/2 79 and M63/2 98, for Mixtophyes abyssalis gen. et sp. nov
The two samples that yielded specimens for the present study were taken with a multicorer in the Guinea Basin at DIVA2 Stations M63/2 79 and M63/2 98, at 5,136-5,142 and 5,165-5,174 m depth, respectively (Fig. 1). The upper $5 \mathrm{~cm}$ of sediment from one core in each multicore sample was fixed in $5 \%$ formaldehyde immediately after collecting. Subsequently, in the laboratory at the Senckenberg Research Institute in Wilhelmshaven, Germany, the fixed samples were washed with freshwater in a $40 \mu \mathrm{m}$ sieve, and meiofauna was extracted from the sediment using centrifugation with the colloidal silica polymer Levasil (see, e.g., Neuhaus and Blasche 2006 for further details). The extracted meiofauna was then sorted to main groups and distributed among some relevant experts.

Of the three specimens representing the new genus and species, two were prepared for light microscopy (LM) and one for scanning electron microscopy (SEM). The specimens for LM were transferred from formaldehyde to water and then dehydrated through a graded series of glycerin. After storage overnight in $100 \%$ glycerin, the specimens were mounted in Fluoromount- $G^{\circledR}$ on a glass slide and sealed with Glyceel ${ }^{\circledR}$. These specimens, as well as the type material of Neocentrophyes intermedius and $N$. satyai, were examined with an Olympus BX51 compound microscope, photographed with Olympus DP20 and DP70 cameras and measured with $\mathrm{Cell}^{\wedge} \mathrm{D}$ software. Line art figures were made with Adobe Illustrator CS4.

The specimen for SEM was also transferred to water, dehydrated through a graded series of ethanol and then through an ethanol-acetone series, until it was contained in $100 \%$ acetone. Then, the specimen was critical point dried, mounted on a SEM stub, sputter coated with a palladium-platinum mix and examined with a JEOL JSM$6335 \mathrm{~F}$ field emission scanning electron microscope.

Terminology related to cuticular feature distribution for homalorhagids follows the standardization criteria established by Sánchez et al. (2011) and adopted by most authors (Sánchez et al. 2013, 2014; Sørensen et al. 2010; Yamasaki et al. 2012), except Neuhaus (2013).

The type material of the new species and genus is deposited at the Museum für Naturkunde (MfN), Humboldt-Universität zu Berlin, in Germany. Specimens of Neocentrophyes intermedius and N. satyai were loaned from the collections of the United States National Museum of Natural History (USNM).

\section{Results}

Taxonomic account

Order Homalorhagida (Zelinka, 1896)

Family Neocentrophyidae Higgins, 1969 
Genus Neocentrophyes Higgins, 1969

Re-examination of Neocentrophyes intermedius Higgins, 1969 and Neocentrophyes satyai Higgins, 1969

\section{Material examined}

All examined specimens of Neocentrophyes intermedius were males mounted for LM, females are not known from the species. The specimens are stored at the USNM:

Holotype, male, collected by R. P. Higgins in the Ambatozavavy Bay, Nosy Bé, Madagascar: $13^{\circ} 21.5^{\prime} \mathrm{S}$, $48^{\circ} 19.5^{\prime} \mathrm{E}, 1-2 \mathrm{~m}$ depth, gray-brown sandy mud, April 15, 1964, accession number RH44.81/USNM37993.

Eight paratypes: four adult males and one juvenile (RH44 series) collected on same date and locality as holotype, accession numbers RH44.76/USNM1207909, RH44.77/ USNM1207910, RH44.78/USNM37994, RH44.82/USNM1 207912 and RH44.80/USNM1207911 (juvenile); one adult male (RH45 series) collected near type locality at 1-2 m depth, from muddy sand, on April 16, 1964, accession number RH45.14/USNM1207913; two adult males (RH51 series), also near type locality, $18 \mathrm{~m}$ depth, gray mud, April 23, 1964, accession numbers RH51.9/USNM1207914 and RH51.10/USNM1207915.

Examined specimens of Neocentrophyes satyai were females, mounted for LM, males are not known from the species. The specimens are stored at the USNM: Damaged holotype, female, collected by R. P. Higgins in the Bay of Bengal, India, $10 \mathrm{~km}$ off $\mathrm{E}$ of Visakhapatnam: $40 \mathrm{~m}$ depth, brown sandy mud, March 26, 1964, accession number RH37.87/USNM37995. Two paratypes (RH44 series), two adult females collected on same date and locality as holotype, accession numbers RH37.88/USNM1207916 and RH37.27/USNM1207917, the latter considered as juvenile by Higgins.

\section{Brief descriptions}

The examined specimens of both species generally agree with the descriptions made by Higgins (1969); hence, the following report only focuses on additional, not previously
Table 1 Measurements $(\mu \mathrm{m})$ of type material of

Neocentrophyes: $N$. intermedius and $N$. satyai. msw maximum sternal width, $s 1-s 11$ 1-11 trunk segments length, $s w 1-s w 11$ sternal width of trunk segments 1-11, TL trunk length

\begin{tabular}{|c|c|c|c|c|c|c|}
\hline \multirow[t]{3}{*}{ Character } & \multicolumn{3}{|c|}{ Neocentrophyes intermedius } & \multicolumn{3}{|c|}{ Neocentrophyes satyai } \\
\hline & \multirow[t]{2}{*}{ Holotype } & \multicolumn{2}{|c|}{7 Paratypes } & \multirow[t]{2}{*}{ Holotype } & \multicolumn{2}{|c|}{2 Paratypes } \\
\hline & & Range & Mean & & Range & Mean \\
\hline $\mathrm{TL}$ & 624 & $471-624$ & 549 & 512 & $436-441$ & 438 \\
\hline msw & 167 & $138-167$ & 154 & 152 & $127-133$ & 130 \\
\hline $\mathrm{msw} / \mathrm{TL}(\%)$ & 26.8 & $24.9-31.6$ & 28.2 & 29.7 & $28.9-30.6$ & 29.7 \\
\hline s1 & 115 & $92-115$ & 100 & - & 75 & 75 \\
\hline s2 & 41 & $36-45$ & 39 & - & $32-33$ & 32 \\
\hline s3 & 46 & $42-53$ & 45 & - & $36-37$ & 36 \\
\hline s4 & 52 & $45-53$ & 49 & - & $36-39$ & 38 \\
\hline s5 & 55 & $47-57$ & 52 & - & $38-39$ & 38 \\
\hline s6 & 62 & $51-62$ & 55 & - & $37-39$ & 38 \\
\hline s7 & 68 & $49-69$ & 57 & - & $41-44$ & 43 \\
\hline s8 & 68 & $51-68$ & 57 & - & $41-47$ & 44 \\
\hline s9 & 69 & $50-69$ & 56 & - & $44-49$ & 46 \\
\hline s10 & 61 & $41-61$ & 50 & - & $41-48$ & 44 \\
\hline s11 & 26 & $18-29$ & 24 & - & $20-23$ & 22 \\
\hline sw1 & 157 & $132-157$ & 144 & 123 & 115-117 & 116 \\
\hline sw2 & 158 & $132-158$ & 147 & 137 & $125-128$ & 126 \\
\hline sw3 & 161 & 134-161 & 148 & 141 & $124-132$ & 128 \\
\hline sw4 & 162 & 134-162 & 151 & 148 & $126-133$ & 129 \\
\hline sw5 & 165 & $133-165$ & 152 & 150 & $127-133$ & 130 \\
\hline sw6 & 166 & 137-166 & 153 & 152 & $127-133$ & 130 \\
\hline sw7 & 167 & 138-167 & 154 & 148 & $126-130$ & 128 \\
\hline sw8 & 163 & 139-163 & 151 & 147 & $125-126$ & 126 \\
\hline sw9 & 156 & $131-156$ & 144 & - & 122 & 122 \\
\hline sw10 & 126 & 108-126 & 116 & - & 105-106 & 106 \\
\hline sw11 & 85 & $68-86$ & 76 & - & 68 & 68 \\
\hline
\end{tabular}


reported information, or cases where our observations are not in concordance with those made by Higgins (1969).

All dimensions and measurements of the examined adult specimens of Neocentrophyes intermedius and N. satyai are summarized in Table 1 and distribution of sensory spots and setae in Tables 2 and 3, respectively (data on arrangement of sensory spots of $N$. satyai refers to the dorsal side only).

Neck Four dorsal and three ventral placids, with the two ventrolateral ones being really soft and inconspicuous (Fig. 2a). Ventral placids appear elongate (Fig. 2a),

Table 2 Summary of location of setae, sensory spots, penile spines, midterminal process and cuticular bulbous protrusions in Neocentrophyes intermedius arranged by series

\begin{tabular}{lllllllll}
\hline Segment & PD & SD & LD & PL & LV & VL & VM & MV \\
\hline 1 & se & ss, ss & ss & se & & se & ss, ss, ss & \\
2 & se & ss & ss, ss, ss & se & & & ss, ss & \\
3 & se & ss & ss, ss & se & & se & ss, ss & \\
4 & se & ss & ss & se & & & ss, ss & \\
5 & se & ss & ss, ss & se & & se & ss, ss & \\
6 & se & ss & ss & se & & se & ss, ss & \\
7 & se & ss & ss & se & & se & ss, ss & \\
8 & se & ss & ss & se & & se & ss, ss & \\
9 & se & ss & ss, ss & se & & se & ss, ss & \\
10 & se & ss & ss & se, ps & & se & ss, ss & \\
11 & & ss 3 & & ps & cbp & & ss3 & mtp \\
\hline
\end{tabular}

cbp cuticular bulbous protrusions of segment $11, L D$ laterodorsal, $L V$ lateroventral, $m t p$ midterminal process, $M V$ midventral, $P D$ paradorsal, $P L$ paralateral, $p s$ penile spines, $S D$ subdorsal, se setae, $s s$ sensory spots (probably type 1 ), ss 3 sensory spots type $3, V L$ ventrolateral, $V M$ ventromedial

Table 3 Summary of location of setae, sensory spots (ventral side only), midterminal process and cuticular bulbous protrusions in Neocentrophyes satyai arranged by series

\begin{tabular}{|c|c|c|c|c|c|c|c|}
\hline Segment & PD & SD & PL & LV & VL & VM & MV \\
\hline 1 & se & & se & & se & ss, ss & \\
\hline 2 & - & & se & & & ss, ss & \\
\hline 3 & - & & se & & se & ss, ss & \\
\hline 4 & se & & se & & & ss, ss & \\
\hline 5 & se & & se & & se & ss, ss & \\
\hline 6 & se & & se & & se & ss, ss & \\
\hline 7 & se & & se & & se & ss, ss & \\
\hline 8 & se & & se & & se & ss, ss & \\
\hline 9 & - & & se & & se & ss, ss & \\
\hline 10 & - & & se & & se & ss, ss & \\
\hline 11 & - & ss 3 & & cbp & & ss 3 & $\mathrm{mtp}$ \\
\hline
\end{tabular}

cbp cuticular bulbous protrusions of segment 11, LV lateroventral, $m t p$ midterminal process, $M V$ midventral, $P D$ paradorsal, $P L$ paralateral, $S D$ subdorsal, se setae, ss sensory spots (probably type 1), ss3 sensory spots type 3, $V L$ ventrolateral, $V M$ ventromedial—data not available
Fig. 2 Neocentrophyes intermedius. Differential interference contrast photographs of males. a, d-m Paratypic males. b, c Holotypic male. a Ventral view of right half of segment 1 . b Detail showing middorsal processes on segments 4-5. c Detail showing middorsal processes on segments 1-3. d Dorsal view of segments 6-8. e Ventral view of right half of segments 2-4. f Dorsal view of segments 6-7. g Left sternal plates on segment 10. h Right sternal plates on segments 5-6. i Left sternal plates on segments 6-7. j Dorsal view on segments 9-11. k Right sternal plates on segments 9-10. 1 Dorsal view on segments 10-11. m Ventral view on segments 9-11. n Segments 10-11, focused medially in specimen. Scale bar $20 \mu \mathrm{m}$. $c b p$ cuticular bulbous protrusion, $f f$ free flap, $m d p$ middorsal process, $m d s$ middorsal spine, $m l p$ midlateral process, $m t p$ midterminal process, $p d s$ paradorsal seta, $p s$ penile spine, $s s p$ single sternal plate, $v l s$ ventrolateral seta, vmss ventromedial sensory spot, $v p l$ ventral placid. Digits following labels refer to segment numbers

whereas dorsal ones are oval (Fig. 3b). Dorsolateral placids are slightly wider than the two central ones.

Trunk Segment 1 with one tergal and one sternal plate, not anteriorly divided on the ventral side (Figs. 2a, 3a). Segments $2-10$ with one tergal and two sternal plates, and segment 11 with one tergal and a single, undivided sternal plate (Figs. $2 \mathrm{~m}, 31-\mathrm{m}$ ). The segment width is nearly constant throughout the anterior $2 / 3$ of the trunk, but it tapers considerably from segment 8 . Maximum width is reached at segment 7 in Neocentrophyes intermedius and at segment 6 in $N$. satyai. The cuticle is of medium thickness with pachycycli and peg and socket joints not well developed. Tergosternal junctions on segments 1-9 and 11 present, but not identified on segment 10 . These junctions are more easily recognizable at the base of the midlateral spinose processes than in the anteriormost region of the segment (Fig. 3h) (except for segment 1). Inconspicuous ventrolateral cuticular ornamentation presents as longitudinal parallel wrinkles in anteriormost region of the first trunk segment. Elongate and narrow muscular scars on segments 2-10 present in subdorsal (adjacent to the subdorsal sensory spots) and ventromedial positions (adjacent to the mesial sensory spots). These muscular scars stretch over most of the segment length, on both dorsal and ventral sides. Scale-like cuticular hairs are evenly distributed on the segments, except around the sensory spots and the muscular scars. Pectinate fringes not visible with LM. Secondary pectinate fringes, cuticular ridges and apodemes (anteromesial thickenings of ventral pachycycli) absent.

Spinose processes and spines Neocentrophyes intermedius has hairy midlateral and middorsal spinose processes on segments 1-9 (Fig. 2b-d, f, j) and N. satyai on segments 1-10 (Fig. 3c, d, h, j). Both species with keel-shaped middorsal and midlateral processes, with an elongate base extending along most of the segment length. Sensory spots or intracuticular atria flanking the spinose processes are absent. N. intermedius with flexible and articulated middorsal spines on segments 10 and 11 (Fig. 2j). N. satyai 

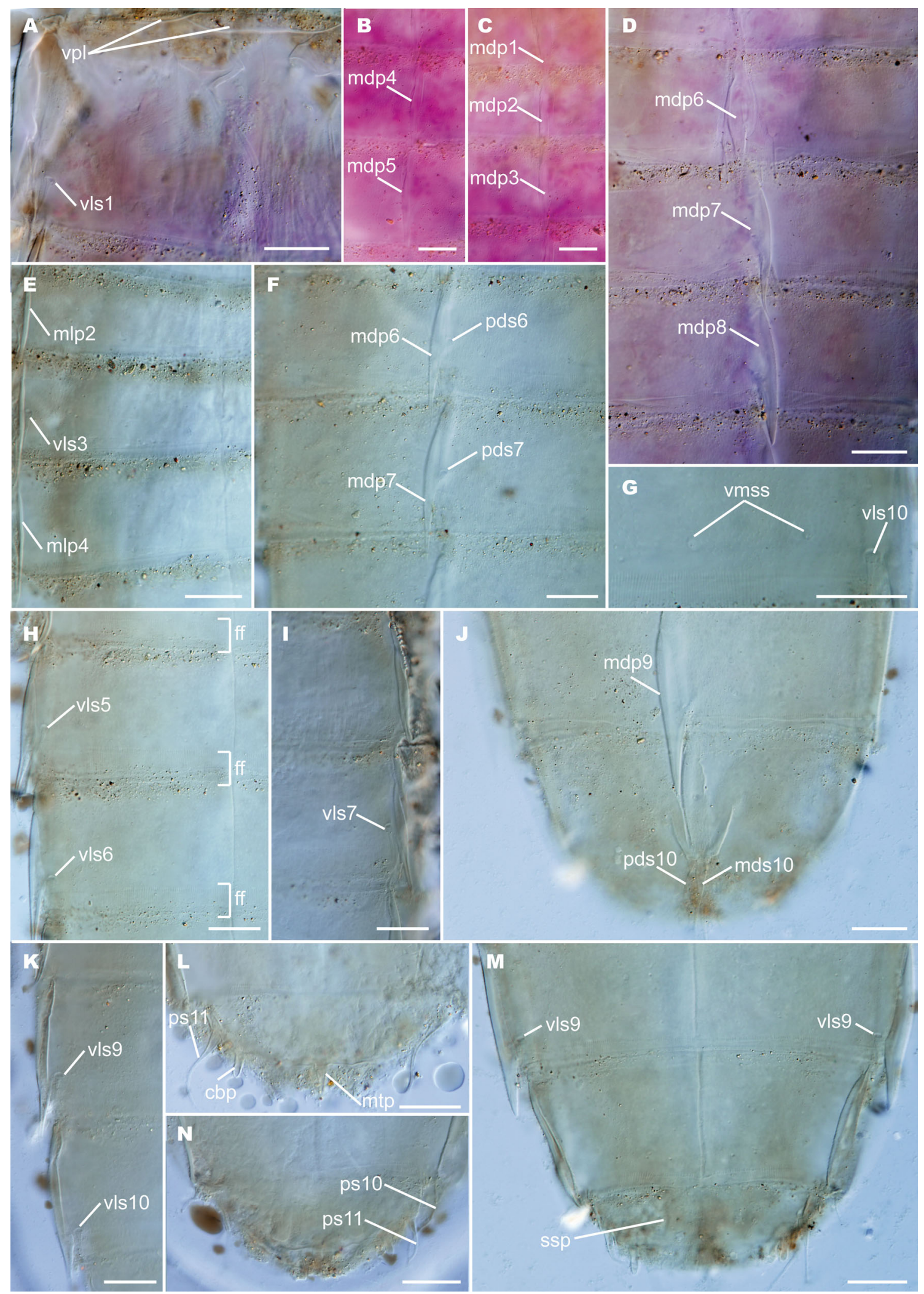

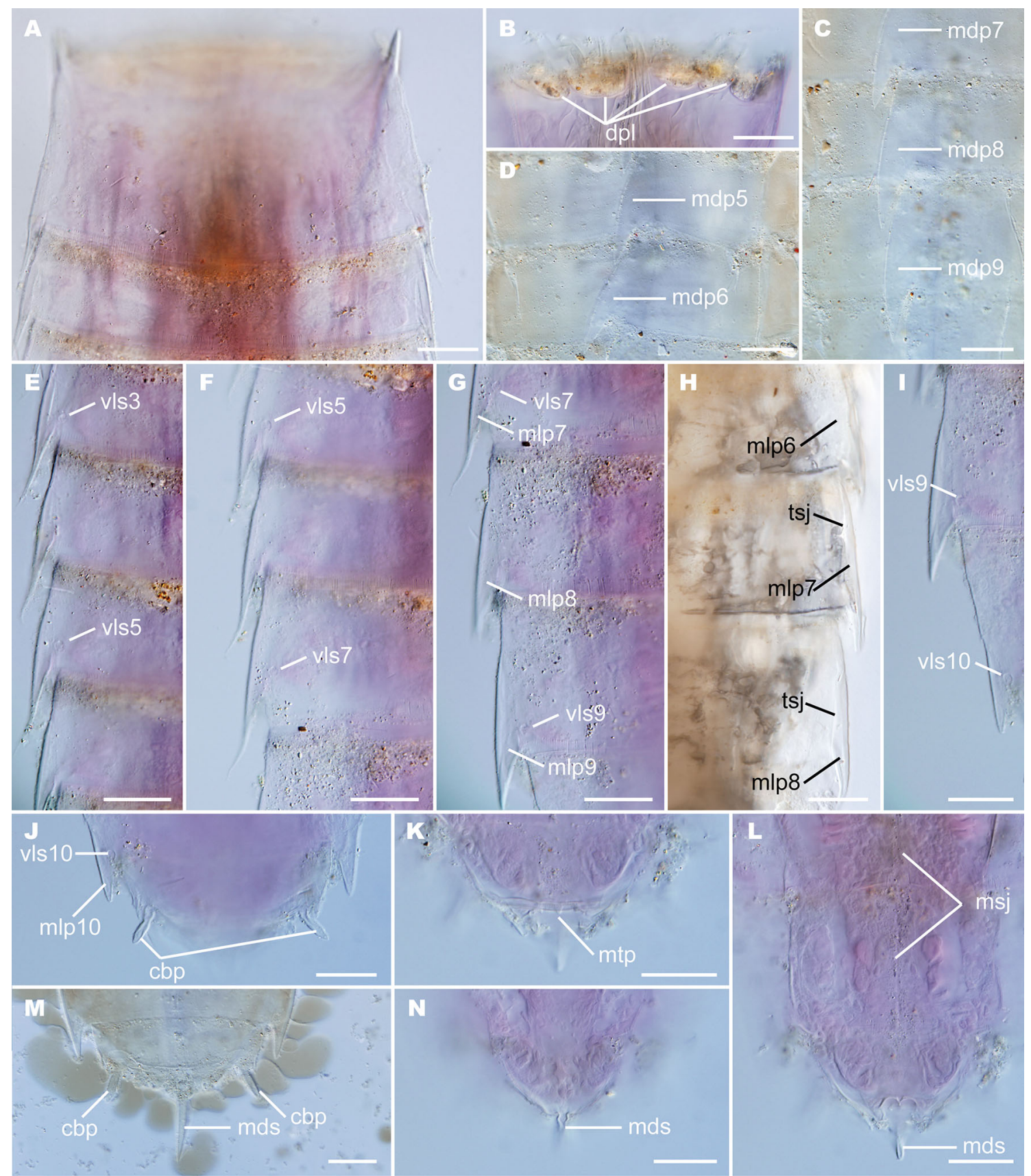

N

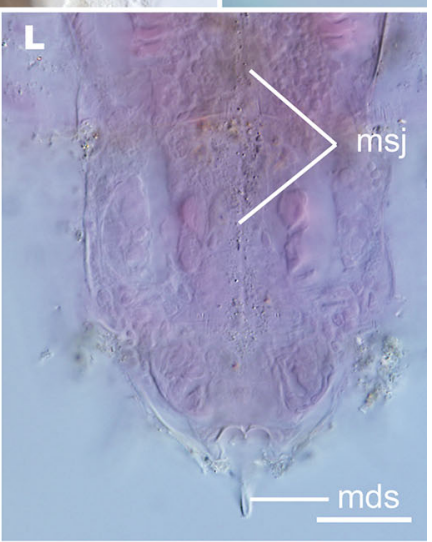

Fig. 3 Neocentrophyes satyai. Differential interference contrast photographs of female paratypes, except for $\mathbf{h}$, showing female holotype. a Ventral view of segments 1-2. b Dorsal placids. c Detail showing middorsal processes on segments 7-9. d Detail showing middorsal processes on segments 5-6. e Ventral view of right sternal plates on segments 3-6. f Ventral view of right sternal plates on segments 5-7. g Ventral view of right sternal plates on segments 7-9. h Ventral view of left sternal plates on segments 6-8. i Ventral view

with an articulated and rigid middorsal spine on segment 11 instead of a middorsal spinose process (Fig. 31-n). Both middorsal and midlateral spinose processes of segments 1-7 are more flexible (Figs. 2b-f, h-i, 3c, d) than those of segments 8 and 9 that appear much more robust and rigid of midlateral processes on segments 9-10. j Ventral view of segments 10-11. k Ventral view of segment 11 . I Ventral view of segments 9-11. m Ventral view of segment 11. $\mathbf{n}$ Dorsal view of segment 11. Scale bar $20 \mu \mathrm{m}$. cbp cuticular bulbous protrusion, $d p l$ dorsal placids, $m d p$ middorsal process, $m d s$ middorsal spine, $m l p$ midlateral process, $m s j$ midsternal junction, $m t p$ midterminal process, $t s j$ tergosternal junction, $v l s$ ventrolateral seta. Digits following labels refer to segment numbers

and with acicular pointed tip (Figs. 2d, j-k, m, 3g, i, j). $N$. intermedius with two pairs of long and flexible penile spines, one attached to segment 10 and one to segment 11 , both in paralateral positions (Fig. $2 \mathrm{l}, \mathrm{n}$ ). N. intermedius with a conspicuous midterminal process on segment 11 , 


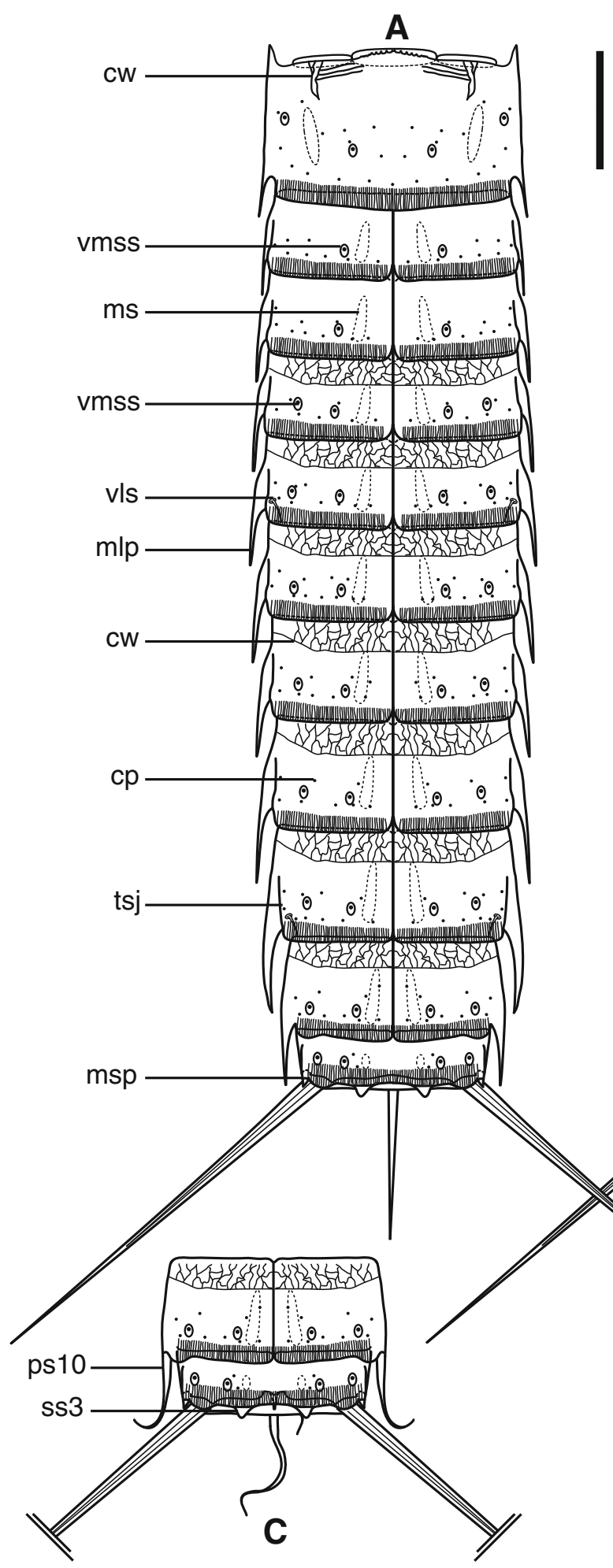

Fig. 4 Line art illustrations of Mixtophyes abyssalis gen. et sp. nov. a Female, ventral view. b Female, dorsal view. c Male, segments 10-11, ventral view. d Male, segments 10-11, dorsal view. Scale bar $100 \mu \mathrm{m}$. $c p$ cuticular pore, $c w$ cuticular wrinkles, $f f$ free flap, ldss laterodorsal sensory spot, $m d p$ middorsal process, $m d s$ middorsal

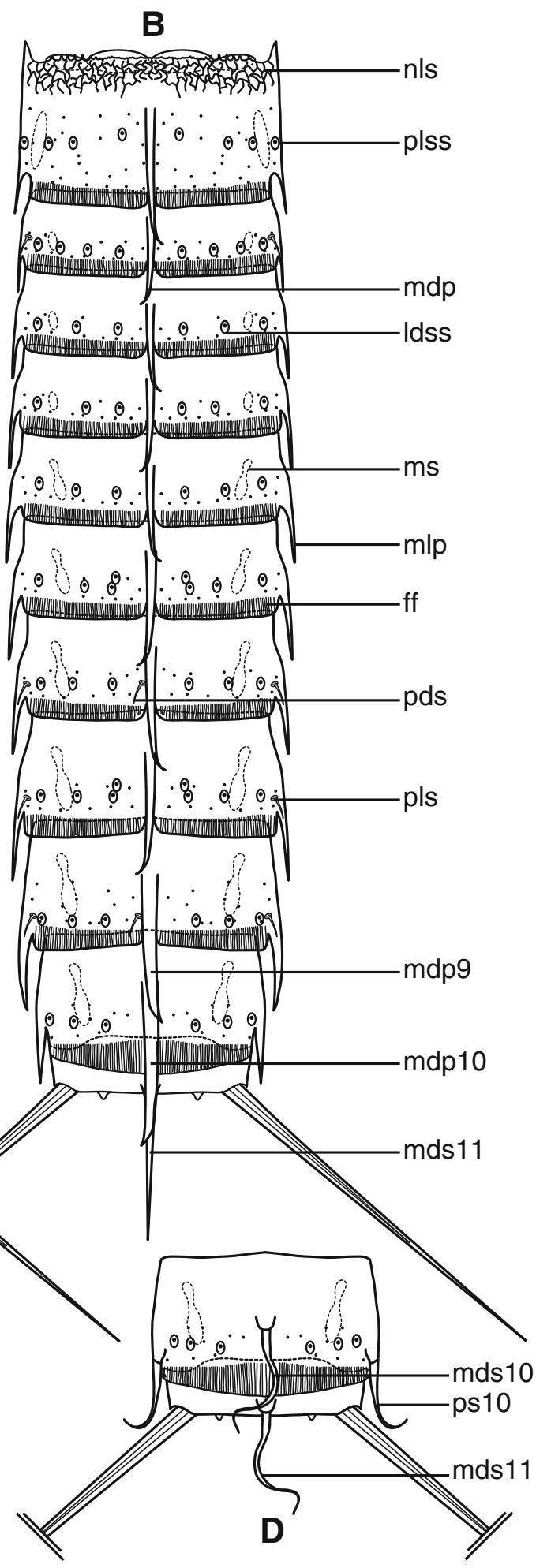

spine, $m l p$ midlateral process, $m s$ muscular scar, $m s p$ minute spine of segment $11, n l s$ net-like structure, $p d s$ paradorsal seta, $p l s$ paralateral seta, $p l s s$ paralateral sensory spot, $p s$ penile spine, $s s 3$ sensory spot type 3, tsj tergosternal junction, vls ventrolateral seta, vmss ventromedial sensory spot. Digits following labels refer to segment numbers 
emerging from a notch in the middle region of the sternal plate (Fig. 2l). Midterminal process of N. satyai is shorter than that of $N$. intermedius (Fig. $3 \mathrm{k}$ ). Segment 11 with one pair of small ventrolateral cuticular bulbous protrusions that are longer in N. satyai than in N. intermedius (Figs. 21, $3 \mathrm{j}, \mathrm{m})$. The bulbous structures are articulated, with thick walls, a central canal and a blunt terminal end.

Setae Paradorsal perispinal setae present on segments 1-10 in Neocentrophyes intermedius (Fig. 2f, j) and at least on segments $1,4-8$ in $N$. satyai. The setae appear either single or in pairs in variable patterns, and their presence are very difficult to confirm in both cases because the middorsal processes usually fold over their position. Pairs of paradorsal perispinal setae were observed on segments 3, 5, 7 and 10 in different specimens of $N$. intermedius, but only those of segment 10 could be clearly observed in all animals. Paralateral perispinal setae were consistently found in both species on segments 1-10 and ventrolateral ones on segments 1, 3, 5-10 (Figs. 2a, e, h-k, m, 3e-g, i-j) (two specimens of $N$. intermedius and one of $N$. satyai-Fig. $3 \mathrm{f}-$ had no ventrolateral perispinal setae on segment 6).

Sensory spots Pairs of subdorsal and ventromedial type 3 sensory spots present on segment 11 only, with the ventromedial pair flanking the midterminal process. Remaining sensory spots throughout the trunk seem to belong to type 1 (but confirmation with SEM is required) and consist of one or two tufts of papillae. Distribution of sensory spots is summarized in Table 2 for Neocentrophyes intermedius and in Table 3 for $N$. satyai.

Genus Mixtophyes gen. nov.

\section{Etymology}

From Latin mixtus-mixed and Greek phyes ( $\phi v \eta \varsigma)$ characterized by a form, the commonly used suffix in homalorhagid genus names. The name refers to the mix of characters from Neocentrophyes and Paracentrophyes observed in the new genus.

Type species: Mixtophyes abyssalis sp. nov.

\section{Diagnosis}

Neocentrophyidae with a single sternal plate on the first trunk segment, without subdivision in its anterior region; pairs of rigid lateral terminal spines on segment 11 in both sexes; females with non-articulated middorsal spinose process on segment 10; males with a single pair of long and flexible penile spines located in paralateral position on segment 10 .

Mixtophyes abyssalis sp. nov. (Figs. 4, 5, 6).
Fig. 5 Mixtophyes abyssalis gen. et sp. nov. SEM micrographs of paratypic male. a Ventral view. b Lateral view. c Ventral view of segments 5-6. d Ventral view of segment 9. e Ventral view of segments 10-11. f Ventral view of segment 1. g Mouth cone and outer oral styles. $\mathbf{h}$ Ventral view showing detail of anteriormost region of segment 1 . i Base of midlateral process and paralateral seta on segment 9. $\mathbf{j}$ Lateral view of segments 7-11. k Detail showing ventromedial sensory spots on left sternal plate on segment 10. I Midlateral process of segment 9 in ventral view. a-b Scale bar $100 \mu \mathrm{m}$. c-l Scale bar $10 \mu \mathrm{m}$, except for $\mathbf{j}, 20 \mu \mathrm{m}$. $\mathrm{cw}$ cuticular wrinkles, $m d p$ middorsal process, $m d s$ middorsal spine, $\mathrm{mlp}$ midlateral process, oos outer oral styles, $p d s$ paradorsal seta, pls paralateral seta, $p o$ protonephridial opening, $p s$ penile spine, ss 3 sensory spot type $3, t s j$ tergosternal junction, $v l s$ ventrolateral seta. Sensory spots are marked with circlets. Digits following labels refer to segment numbers

\section{Etymology}

From Latin abyssus, abyss, deep-sea; referring to the sampling localities at 5,136-5,174 $\mathrm{m}$ depth in the Atlantic Ocean where the new species was found.

\section{Type material}

Holotype, adult female, collected on March 23, 2005, in the Guinea Basin at DIVA2 Station M63/2 98, position: $00^{\circ} 37^{\prime} 12^{\prime \prime} \mathrm{N}, \quad 006^{\circ} 28^{\prime} 06^{\prime \prime} \mathrm{W}$ (Fig. 1), from mud at 5,165-5,174 m depth, mounted in Fluoromount $\mathrm{G}^{\circledR}$, stored at the MfN under accession number: ZMB 11516. Two paratypes, adult males: one collected on March 19, 2005, in the Guinea Basin at DIVA2 Station M63/2 79, position: $00^{\circ} 50^{\prime} 00^{\prime \prime} \mathrm{N}$, $005^{\circ} 35^{\prime} 00^{\prime \prime} \mathrm{W}$ (Fig. 1), from mud at 5,136-5,142 $\mathrm{m}$ depth, mounted in Fluoromount $\mathrm{G}^{\circledR}$, and stored at the MfN under accession number: ZMB 11517; and the other one collected at same date and locality as allotype, mounted for SEM, stored at the MfN under accession number: ZMB 11518.

\section{Diagnosis}

Same as genus diagnosis combined with presence of large middorsal spinose processes on segments 1-9 with similar size from segment 1 to 6 and increasing in length toward the posterior trunk segments; single (left) paradorsal perispinal seta on segments 7 and 9, pairs of paralateral setae on segments 2, 7-9 and ventrolateral setae on segments 1 (in males only), 5 and 9; pairs of very minute ventrolateral spines on segment 11; cuticular ornamentation of the anterior margin of first trunk segment as wrinkles, dorsally and ventrolaterally; type 1 sensory spots consisting of one or two tufts of papillae around a central pore.

\section{Description}

All dimensions and measurements of the examined specimens are summarized in Table 4 and distribution of sensory spots and setae in Table 5. 


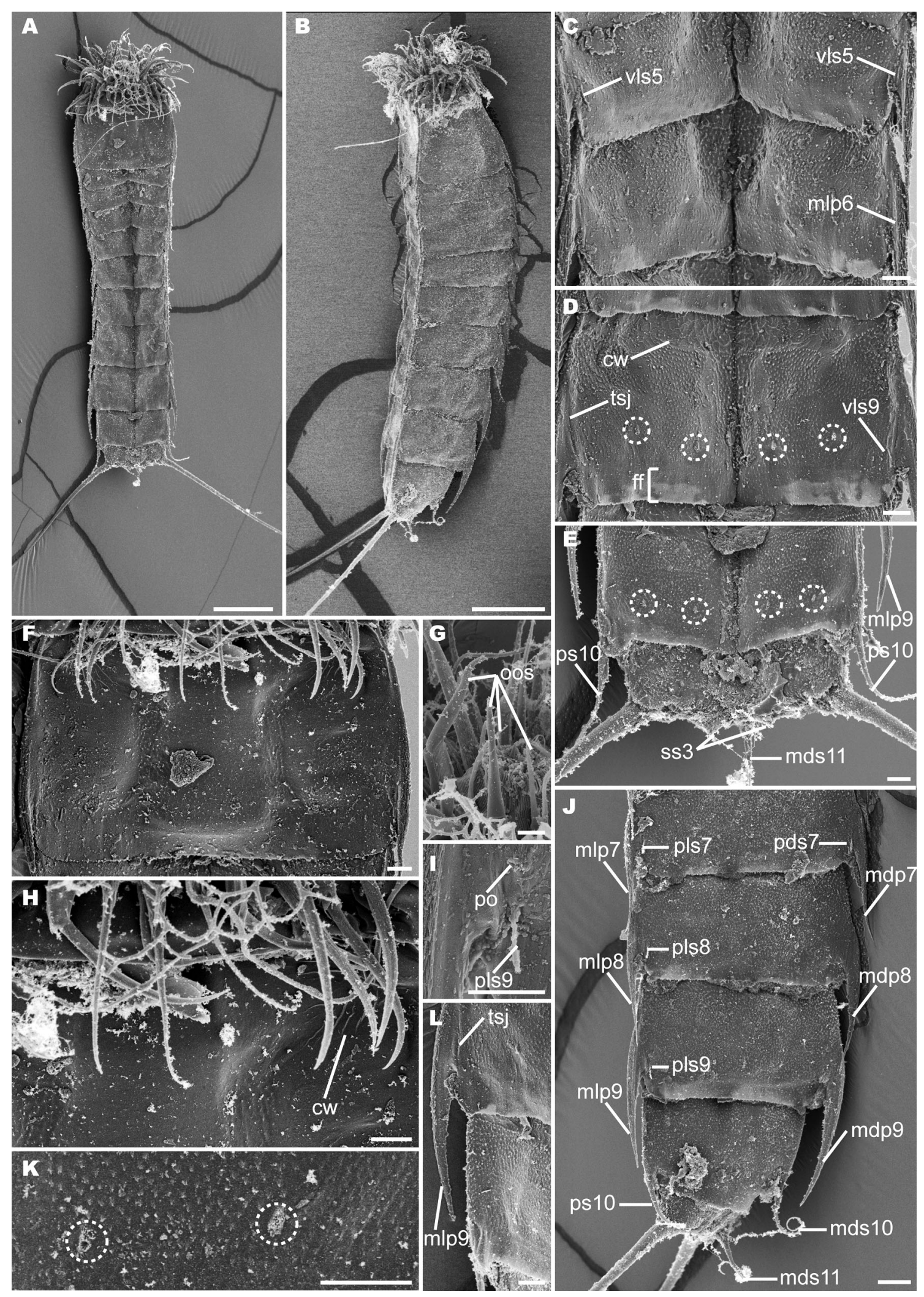


Mouth cone Cuticular surface of mouth cone with longitudinal wrinkles, and nine outer oral styles attached distally. Two kinds of outer oral styles: five large and welldeveloped styles consisting of two articulating units, alternating with four smaller, non-articulated ones.

Neck Four dorsal and three ventral placids; ventrolateral ones appear soft and inconspicuous in LM. Remaining placids are more robust, with concave surfaces. The two medial dorsal placids are slightly wider than the more lateral ones. The rectangular midventral placid is broad, up to $1 / 3$ of the segment width (Fig. $6 \mathrm{~g}$ ).

Trunk Eleven segments in trunk (Figs. 4a, b, 5a, b, 6a, b), with the first one consisting of one tergal and one sternal plate, without any complete or partial subdivision in the anterior region of the sternal plate (Figs. $4 \mathrm{a}, 5 \mathrm{a}, \mathrm{f}, \mathrm{h}$, $6 h)$. Segments 2-10 with one tergal and two sternal plates and segment 11 with one tergal and a single sternal plate (Figs. 4a, c, 6a, k). Sternal plates are flattened, whereas the tergal plate is vaulted, giving the trunk a triangular shape in cross-section. The segment width is rather constant along the trunk, reaching its maximum sternal width at segment 7 and tapering progressively from this point toward the terminal segment. Tergosternal junctions are clearly observed on segments 1-9 and 11, whereas they could not be identified on segment 10 (Figs. 4a, c, 5d, 1, 6f). Markings of the tergosternal junctions are not equally developed along the segments, and they are easily observed at the bases of the midlateral spinose processes, whereas they are inconspicuous in the anteriormost parts of the segments (except for segment 1). Segments 1-9 with middorsal spinose processes pointing backward and extending over the following segment. The middorsal spinose processes are of similar size on segments 1-6 and then increase progressively in length toward the posterior segments 7-9 (Figs. 4b, 5b, j, $6 b)$. Males with articulated, flexible and soft middorsal spines on segments 10 and 11 (Figs. 4d, 5j); females with one non-articulated, rigid and robust middorsal spinose process on segment 10 and one articulated, robust middorsal spine on segment 11 (Figs. 4b, 6b, e). Neither intracuticular atria nor paradorsal sensory spots are present at any segment (Fig. 6b). Hairy midlateral spinose processes with acicular pointed tips are present on segments 1-9 in males and 1-10 in females (Figs. 4a-c, 5a, b, 6a, b). Trunk surface with numerous cuticular pores (Figs. 4a-d, 6c, i) and scale-like cuticular hairs, the latter being absent around the sensory spots and muscular scars (Figs. 5k, 6i). Segments 4-10 with cuticular wrinkles in the anteriormost region of the sternal plates (Figs. 4a, c, 5d). Most segments with two pairs of muscular scars, located in laterodorsal (segments 1-10) and ventromedial (segments 1-11) positions (Fig. 4a-d); ventral muscular scars on segment 1 located more lateral than those of the remaining segments. The laterodorsal scars are large, elongate and oval on
Fig. 6 Mixtophyes abyssalis gen. et sp. nov. Differential interference contrast photographs. a-c, e-k Holotypic female. d Paratypic male (ZMB 11517). a Ventral view. b Dorsal view. c Dorsal view of left half of segment 1. d Dorsal view of segments 8-9. e Middorsal process and spines on segments 10-11. f Right sternal plates on segments 9-10. g Ventral placids. $\mathbf{h}$ Ventral view of segment 1. i Dorsal view of left half of segments 2-3. j Midlateral process of segment 7. $\mathbf{k}$ Ventral view of segments 10-11. Scale bar $20 \mu \mathrm{m}$, except for d, $50 \mu \mathrm{m}$. $c p$ cuticular pore, $c w$ cuticular wrinkles, $f f$ free flap, $m d p$ middorsal process, $m d s$ middorsal spine, $m l p$ midlateral process, $m s p$ minute spine of segment $11, n l s$ net-like structure, $p l s$ paralateral seta, $s s 3$ sensory spot type $3, t s j$ tergosternal junction, $v p l$ ventral placid. Sensory spots are marked with circlets, except on $\mathrm{D}$, where the circlet marks the gonad with sperm. Digits following labels refer to segment numbers

segment 1, smaller and more rounded on segments 2-4 and tenpin shaped on segments 5-10, whereas the ventromedial ones are elongate (Fig. 4a-d). Free flaps of tergal and sternal plates are striated and well developed, overlapping a broad portion of the anterior area of the following segment (Figs. 4a, b, 5d, 6f, i). Inconspicuous pectinate fringes are present on dorsal and ventral sides, visible with SEM only. Secondary pectinate fringes, cuticular ridges and apodemes absent. Pachycycli and peg and socket joints not well developed (Fig. 6a, b).

Segment 1 Anterolateral margins of tergal plate projecting into horn-like extensions (Fig. 4a, b). Anterior edge of tergal plate strongly denticulated, followed by a band of cuticular wrinkles forming a reticulate net-like ornamentation all along the anterior margin (Figs. 4b, 6c). Middorsal spinose process with an elongate base and a flexible terminal end (Figs. 5b, 6c). This conspicuous, keel-shaped structure begins at the anterior third of the segment and surpasses half of the following segment. A longitudinal band of short cuticular hairs stretches along the basal part of the process. Sensory spots on the tergal plate include one subdorsal, two laterodorsal and one paralateral pairs (Figs. 4b, 6c). Sensory spots on this and all following segments belong to type 1 and consist of numerous small papillae located anterior to one or two tufts of 8-10 larger cuticular papillae. Each tuft of 8-10 papillae is arranged around a central pore (Fig. 5k). No cilia have been observed emerging from the central pores. Ventral side with a single sternal plate, neither complete nor partial subdivision (Figs. 4a, 5a, f, h, 6h). Anterior edge of sternal plate denticulated, similar to that of the tergal plate. Anterolateral area of sternal plate with conspicuous transverse and longitudinal cuticular wrinkles; central anterior area smooth (Figs. 4a, 5f, h, 6g, h). Midlateral spinose processes covered by short hairs and flanked by ventrolateral perispinal setae in males (absent in females). Pairs of ventromedial and ventrolateral sensory spots present, the latter located more anteriorly. Scale-like cuticular hairs cover the posterior half of the segment (Fig. 5f). Deep, rounded notches appear at the free flap on both sides of the middorsal and midlateral spinose processes (Figs. 4a, b, 5f). 


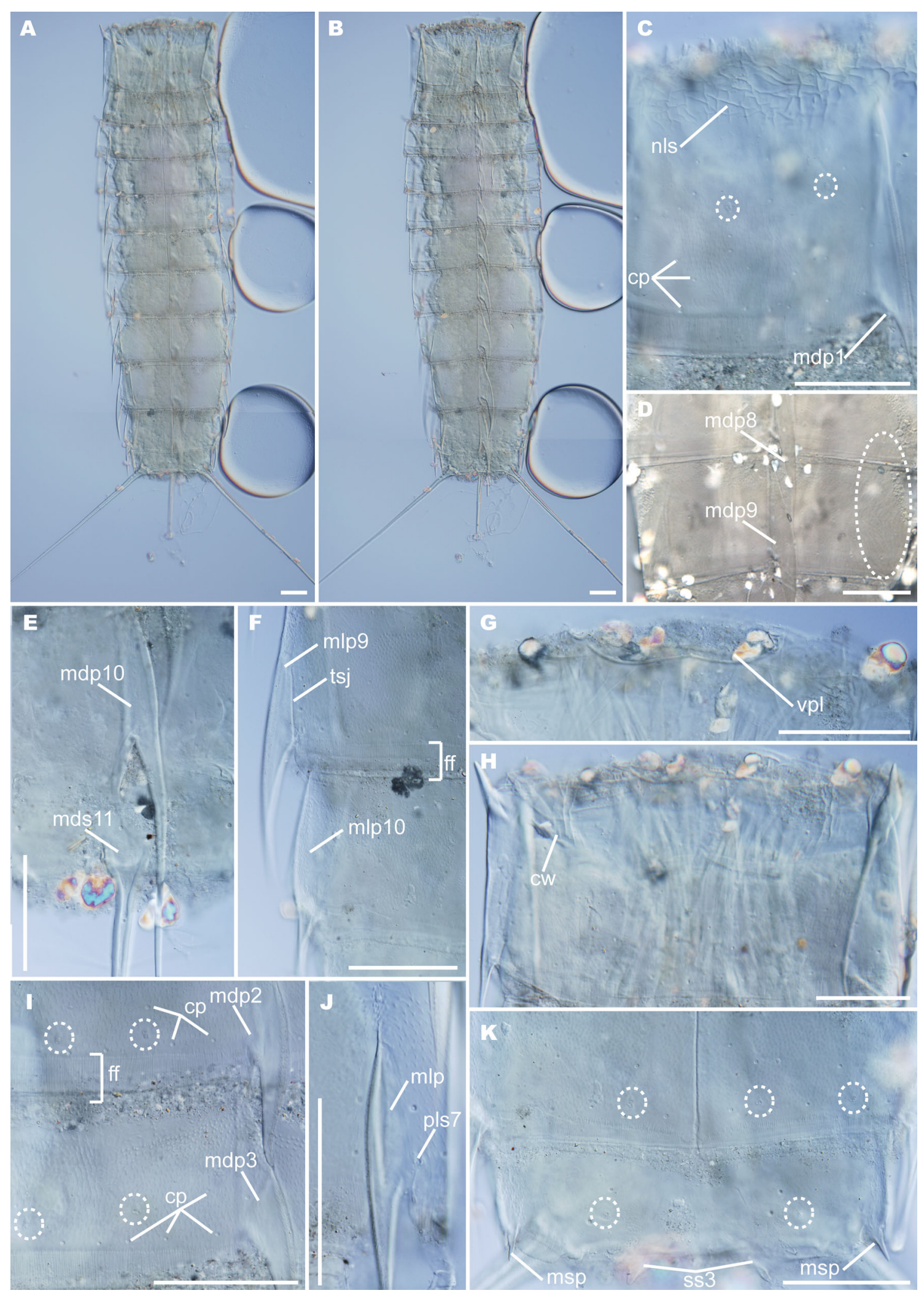


Table 4 Measurements $(\mu \mathrm{m})$ of female holotype and male paratype (ZMB 11517) of Mixtophyes abyssalis gen. et sp. nov

\begin{tabular}{|c|c|c|}
\hline Character & Holotype $q$ & Paratype \\
\hline $\mathrm{TL}$ & 871 & 769 \\
\hline msw/TL (\%) & 24.3 & 27.7 \\
\hline lts/TL (\%) & 40.8 & 61.1 \\
\hline s1 & 131 & 121 \\
\hline s2 & 66 & 65 \\
\hline s3 & 67 & 76 \\
\hline s4 & 70 & 76 \\
\hline s5 & 78 & 77 \\
\hline s6 & 81 & 79 \\
\hline s7 & 88 & 82 \\
\hline s8 & 93 & 88 \\
\hline s9 & 98 & 96 \\
\hline s10 & 86 & 78 \\
\hline s11 & 47 & 47 \\
\hline sw1 & 205 & 210 \\
\hline sw2 & 197 & 209 \\
\hline sw3 & 202 & 210 \\
\hline sw4 & 208 & 209 \\
\hline sw5 & 210 & 210 \\
\hline sw6 & 211 & 211 \\
\hline sw7 & 212 & 213 \\
\hline sw8 & 205 & 209 \\
\hline sw9 & 192 & 203 \\
\hline sw10 & 167 & 180 \\
\hline sw11 & 146 & 456 \\
\hline lts & 355 & 470 \\
\hline mds11 & 146 & 82 \\
\hline
\end{tabular}

lts lateral terminal spine, $m d s 11$ middorsal spine of segment $11, m s w$, maximum sternal width, s1-s11 1-11 trunk segments length, sw1-sw11 sternal width of trunk segments $1-11 ; T L$ trunk length
Segment 2 Tergal plate with large middorsal and midlateral spinose processes similar to those on the preceding segment (Figs. 4a, b, 6i). Pairs of perispinal setae in paralateral positions appear to be present in both sexes (Fig. 4b). One pair of subdorsal and three pairs of laterodorsal sensory spots present (Fig. 6i). Pairs of laterodorsal muscular scars present between the two pairs of sensory spots located most laterally, on this and all following segments (Fig. 4b). Sternal plates with one pair of ventromedial sensory spots and muscular scars, the latter located mesially, adjacent to the sensory spots and almost in paraventral position (Fig. 4a).

Segment 3 Tergal plate similar to that of segment 2 (Fig. 6i), but without setae. One pair of subdorsal and two pairs of laterodorsal sensory spots present. The most mesial pair of laterodorsal sensory spots appears to be slightly laterally displaced (Figs. 4b, 6i). Sternal plates as on segment 2 .

Segment 4 Tergal plate similar to that on segment 3 , but with the laterodorsal pair of sensory spots located more mesially, aligned with those of segment 2 . Sternal plates as those on segment 2, but with an additional pair of ventromedial sensory spots, located more laterally (Fig. 4a).

Segment 5 Tergal plate similar to that on segment 3 and sternal plates as those on segment 4 , but with one pair of ventrolateral perispinal setae (Figs. 4a, 5c).

Segment 6 Tergal and sternal plates similar to those on segment 4 (Fig. 5c), but females with an additional pair of subdorsal sensory spots located close and anterior to the other subdorsal pair (Fig. 4b).

Segment 7 Tergal plate similar to that on segment 3, but with one pair of paralateral perispinal setae (Figs. 4b, 6j), and with a single paradorsal perispinal seta on the left side

Table 5 Summary of location of setae, sensory spots, spines and midterminal process in Mixtophyes abyssalis gen. et sp. nov. arranged by series

\begin{tabular}{|c|c|c|c|c|c|c|c|c|}
\hline Segment & PD & SD & $\mathrm{LD}$ & PL & LV & VL & VM & MV \\
\hline 1 & & ss & ss, ss & ss & & $\mathrm{se}(\mathrm{m}), \mathrm{ss}$ & ss & \\
\hline 2 & & ss & ss, ss, ss & se & & & ss & \\
\hline 3 & & ss & ss, ss & & & & ss & \\
\hline 4 & & ss & ss, ss & & & & ss, ss & \\
\hline 5 & & ss & ss, ss & & & se & ss, ss & \\
\hline 6 & & ss, ss(f) & ss, ss & & & & ss, ss & \\
\hline 7 & $\mathrm{se}^{*}$ & ss & ss, ss & se & & & ss, ss & \\
\hline 8 & & ss, ss(f) & ss, ss & se & & & ss, ss & \\
\hline 9 & $\mathrm{se}^{*}$ & ss & ss, ss & se & & se & ss, ss & \\
\hline 10 & & ss & ss, ss & $\mathrm{ps}(\mathrm{m})$ & & & ss, ss & \\
\hline 11 & & ss3 & & & lts & msp & ss, ss, ss 3 & $\mathrm{mtp}(\mathrm{m})$ \\
\hline
\end{tabular}

$f$ female condition of sexually dimorphic character, $L D$ laterodorsal, lts lateral terminal spines, $L V$ lateroventral, $m$ male condition of sexually dimorphic character, $m s p$ minute spine of segment $11, m t p$ midterminal process, $M V$ midventral, $P D$ paradorsal, $P L$ paralateral, $p s$ penile spines, $S D$ subdorsal, se setae, ss sensory spots type 1, ss 3 sensory spots type 3, $V L$ ventrolateral, $V M$ ventromedial

* marks that the seta is unpaired 
of the middorsal process. Middorsal and midlateral spinose processes more elongated, reaching the posterior third of the following segment (Figs. 5a, b, j, 6b). Sternal plates as on segment 4.

Segment 8 Tergal and sternal plates similar to those on segment 6 , but with one pair of paralateral perispinal setae (Fig. 4b). Middorsal and midlateral spinose processes with thicker bases (Figs. 5a, b, j, 6b).

Segment 9 Tergal plate similar to that on segment 7, but with larger middorsal and midlateral spinose processes; both structures with rigid tips, contrary to the more flexible ones of the preceding segments (Figs. 5j, 1, 6a, b, f). Paralateral protonephridial opening surrounded by several minute hairs, not sieve-like (Fig. 5i). Sternal plates similar to those on segment 4 , but with one pair of ventrolateral perispinal setae (Fig. 5d).

Segment 10 Males with a flexible and soft middorsal spine (articulated) departing from the medial portion of the segment (Figs. 4d, 5j) and extending far beyond the posterior end of the trunk (Fig. 5c, d). Posterior dorsal margin of the segment straight in males, not interrupted by notches in subdorsal position (Fig. 5j). Furthermore, males without midlateral spinose processes, but with one pair of long and flexible paralateral penile spines (Figs. 4c, d, 5e, j). Females with a robust, rigid and pointed middorsal spinose process (non-articulated), similar to that characterizing the preceding segment (Figs. 4b, 6e), and extending far beyond the posterior end of the trunk segment (Figs. 4a, b, 6a, b). Midlateral spinose processes shorter than the middorsal one (Figs. 4a, b, 6a, b). Posterior dorsal margin in females with notches at both sides of the middorsal spinose process. Both sexes with three pairs of sensory spots present, one in subdorsal and two in laterodorsal positions. Sternal plates with two pairs of ventromedial sensory spots (Figs. 5e, k, $6 \mathrm{k}$ ), both located in the same position as those on the preceding segments. Posterior ventral margin of the segment straight, but with extensions in the ventrolateral areas (Figs. 5e, 6k).

Segment 11 One tergal and a single sternal plate (Figs. 4a, c, 6k). Both sexes with middorsal spines (articulated) and one pair of robust, lateral terminal spines. Midlateral spinose processes not present. The middorsal spine of males is similar to that on segment 10 (Figs. 4c, d, 5e, j). Contrarily, the middorsal spine of females appears more like the middorsal process of segment 10, being robust, rigid and pointed (Fig. 6b). However, its internal structure is remarkably different. It is not constituted by a single piece, but appears articulated, divided into two parts, and attaches to the posterior portion of the segment (Fig. 6e). Males without penile spines on this segment (Figs. 4c,d, 5e, j), and with a tiny midterminal process, emerging from a notch in the medial region of the plate (Fig. 6k). Both sexes with two pairs of ventromedial sensory spots on sternal plates (Fig. 6k). Type
3 sensory spots present in subdorsal and ventromedial positions, protruding from the posterior margin of the segment (Figs. 5e, 6k). One pair of very minute, conical ventrolateral spines present (Figs. 4a, c, 6k). The posterior margin of the segment is straight along the dorsal side, whereas the ventral one has two extensions over the lateral terminal spines, partly covering the minute ventrolateral spines (Figs. 5e, 6k).

\section{Summary of sexually dimorphic characters}

Males with a flexible middorsal spine (articulated) on segment 10; females with middorsal spinose process (nonarticulated) instead. Middorsal spine (articulated) on segment 11 present in both sexes, rigid in females and flexible and shorter in males. Males without midlateral spinose processes on segment 10; females with well-developed and rigid spinose process. Females with one additional pair of subdorsal sensory spots on segments 6 and 8. Furthermore, males characterized by one pair of paralateral penile spines on segment 10 , midterminal process and one pair of ventrolateral perispinal setae on segment 1 .

\section{Associated kinorhynch fauna}

Several other kinorhynch species co-occurred with $M$. abyssalis gen. et sp. nov. Station M63/2 79 revealed three conspecific specimens (two adults and one juvenile) that could not be identified to genus level. These organisms resemble both Antygomonas and Sphenoderes; further studies are needed for a detailed description. The sampled sediment also contained juveniles and adults of a new species of Echinoderes with middorsal spines on segments 4-8, lateroventral spines/tubes on segments 5-10, dorsolateral spines on segment 2 and lateral accessory tubes on segment 8. Station M63/2 98 contained several specimens of Echinoderes spp. and two new species of Pycnophyes.

\section{Discussion}

Re-examination of Neocentrophyes intermedius and $N$. satyai

Re-examination of the type series of the two known Neocentrophyes species revealed novel information about their morphology, and it also enabled us to correct some details in the original description (Higgins 1969). First of all, the examination revealed new details about the cuticular ornamentation of segment 1 , information on the sensory spot distribution along the trunks of the two species, together with the absence of apodemes, cuticular ridges and secondary pectinate fringes along the segments. 
Nevertheless, the re-examination confirmed traits reported in the original description, while revealing some shortcomings, some of which being rather important. Most importantly, it showed that the sternal plate of the terminal segment is undivided and hence not differentiated into two sternal plates as originally reported (Higgins 1969). This particular character could be of interest in a comparative aspect, since it varies between the homalorhagid genera. Among species of Pycnophyes and Kinorhynchus, segment 11 is consistently through the genera composed of one tergal and two sternal plates (e.g., Higgins 1983; Adrianov and Malakhov 1999; Sánchez et al. 2011, 2014), whereas the three known species of Paracentrophyes and Mixtophyes abyssalis gen. et sp. nov. have a single sternal plate in the terminal segment (Higgins 1983; Sørensen et al. 2010; present contribution).

Additional details differing from the original description by Higgins (1969) include: (a) the position of the penile spines, the first pair being placed on segment 10 and the second pair on segment 11, and not both pairs located on segment 11; (b) the occurrence of a middorsal, basally articulating spine, and not a spinose process on segment 11 in females; (c) the absence of ventrolateral setae on segment 4 (originally reported as present). The latter may seem to be an irrelevant detail, but since distribution of setae appears to be a diagnostic character among homalorhagid species, this information would be important in the future if new species of Neocentrophyes were found.

Based on the added and corrected information, emended diagnoses for Neocentrophyidae and Neocentrophyes are included below.

Originally, Neocentrophyes intermedius and N. satyai were described as two distinct species by Higgins (1969), but later Higgins (1983) considers whether the two entities in fact could represent male and female of the same species. This possibility appears very likely, as the two species are mainly distinguished by characters that usually relate to sexual dimorphism. However, the geographic distance between the species' type localities, Madagascar for $N$. intermedius and Bay of Bengal for N. satyai obviously argues against this hypothesis, but then again, India and Madagascar were actually connected and part of Gondwana, and their tectonic plates did not separate before late Cretaceous, about 90 mya. Of course, one would expect that 90 million years' genetic separation of the Madagascan and Indian populations would have result in separate speciation at some point, but at least a paleohistorical connection between the two species or populations exists. Currently, it is impossible to determine whether $N$. intermedius and $N$. satyai are conspecific or not, hence new sampling near the species' type localities in order to collect male $N$. satyai and female $N$. intermedius would be required to answer the question.
Diagnostic characters in Mixtophyes abyssalis gen. et sp. nov

Mixtophyes abyssalis gen. et sp. nov. is obviously closely related to the homalorhagid genera Pycnophyes, Kinorhynchus, Paracentrophyes and Neocentrophyes and displays several typical homalorhagid traits, such as the almost rectangular outline of the trunk, the arrangement of the placids and the general absence of spines on segments $1-9$. The new genus and species is, however, also easily distinguished from species of Kinorhynchus and Neocentrophyes by the presence of lateral terminal spines, which are lacking in species of the two mentioned genera (Zelinka 1928; Sheremetevskij 1974; Higgins 1969). It is also distinguished from species of Pycnophyes by its composition of the sternal plate on segment 1 , being formed from a single plate and without traces of a subdivision, whereas the sternal plate is subdivided into one midsternal and two episternal plates in Pycnophyes (see, e.g., Higgins 1983; Sánchez et al. 2011, 2014). Perhaps M. abyssalis gen. et sp. nov. shows the closest resemblance to the species of Paracentrophyes, as they also have lateral terminal spines and an undivided sternal plate on segment 11. However, species of Paracentrophyes are characterized by having a sternal plate on segment 1 with partially developed lines, marking an incomplete differentiation into epi- and midsternal plates (Higgins 1983; Sørensen et al. 2010), whereas M. abyssalis gen. et sp. nov. has no markings at all on the sternal plate of segment 1 .

Hence, the combination of a single sternal plate on segment 1 without partial subdivision, and lateral terminal spines, makes M. abyssalis gen. et sp. nov. unique among homalorhagids.

Notes on selected morphological characters in $M$. abyssalis gen. et sp. nov.

Besides the composition of segment 1 , some additional characters deserve a special attention in M. abyssalis gen. et sp. nov. The cuticle generally appears rather thin, and pachycycli and peg and socket joints are very indistinct. This is also common for other species of Neocentrophyidae (see e.g., Higgins 1969, 1983), whereas these structures appear much more well developed in species of Pycnophyidae (Kristensen and Higgins 1991). The presence of keel-shaped middorsal and midlateral spinose processes, with flexible posterior ends, is also shared with all other species of Neocentrophyidae (Zelinka 1928; Higgins 1969, 1983; Sørensen et al. 2010), whereas adult individuals of species of Pycnophyidae do not have midlateral processes and the middorsal ones are never flexible (Sánchez et al. 2011). Most sensory spots of the new genus and species belong to type 1 (see Nebelsick 1992), mainly consisting of 
one or two tufts of 8-10 cuticular papillae, each arranged around a central pore. Similar sensory spots have been found in all species of Neocentrophyidae (Higgins 1983; Neuhaus 1995; Sørensen et al. 2010; present contribution) but only in two species of Pycnophyidae (Adrianov and Malakhov 1994; Sánchez et al. 2014). Also the secondary pectinate fringes are lacking in Mixtophyes abyssalis gen. et sp. nov., which again is a trait shared with species of Neocentrophyes and Paracentrophyes (Higgins 1969, 1983; Sørensen et al. 2010; present contribution). Contrarily, most Pycnophyes and Kinorhynchus species have one or several secondary pectinate fringes that usually appear very conspicuous at SEM (Higgins 1983; Sánchez et al. 2011, 2013, 2014).

Sexual dimorphism in species of Pycnophyes and Kinorhynchus is usually expressed through the presence of two or three pairs of penile spines on the last trunk segment and one pair of large ventral tubes on segment 2 (supposedly, only five out of 54 species of Pycnophyes species lack these structures, see Neuhaus 2013). Contrarily, males of Neocentrophyes and Paracentrophyes always bear only two pairs of flexible and long penile spines, one on segment 10 and one on segment 11, and lack the large ventral tubes on segment 2 (Higgins 1969, 1983; Kristensen and Higgins 1991, Sørensen et al. 2010). Males of Mixtophyes abyssalis gen. et sp. nov. have only a single pair of flexible and long penile spines, located on segment 10 , and the ventral tubes on segment 2 are missing. Males of Paracentrophyes, Neocentrophyes and Mixtophyes gen. nov. share the presence of soft and flexible middorsal spines on segments 10 and 11. However, females of Paracentrophyes have rigid middorsal spines on segments 10 and 11, whereas females of Neocentrophyes and Mixtophyes gen. nov. have rigid middorsal spine (articulated) on segment 11 only, and instead a middorsal process (hence, non-articulated) on segment 10 (Higgins 1969, 1983; Sørensen et al. 2010).

\section{Phylogenetic position and taxonomic status of the new} taxon

Kinorhynch phylogeny, and hence also homalorhagid phylogeny, was recently addressed in two studies based on molecular sequence data from 18S rRNA (Dal Zotto et al. 2013) and combined 18S rRNA and 28S rRNA (Yamasaki et al. 2013). The results of the two studies are congruent in several ways, e.g., they confirm a close relationship between species of Pycnophyes and Kinorhynchus and they indicate that Dracoderes is a homalorhagid taxon as well. Dal Zotto et al. (2013) also suggest that the aberrant genus Franciscideres (and perhaps even Cateria) is more closely related to the homalorhagids or it could be a very basal homalorhagid or even a basal kinorhynch. However, none of the two studies were able to include sequence data from a representative of Neocentrophyes, and even though data were included for Paracentrophyes anurus Sørensen et al., 2010 , it was not possible for any of the studies to clarify its exact position inside Homalorhagida.

More information about the phylogenetic position of these two particular genera would have been desirable, since Mixtophyes abyssalis gen. et sp. nov.-based on the characters discussed above-shows some affinities to both of them. However, the results from Yamasaki et al. (2013) and Dal Zotto et al. (2013) can still be helpful and with a few assumptions, based on the observed morphological traits, it would be possible to establish a tentative position of Mixtophyes gen. nov. until more data become available.

First, the typical overall appearance of the four original homalorhagid taxa, i.e., the stout, rectangular trunk with almost parallel sides; represents a derived condition, opposed to the more spindle-shaped trunk, found in Dracoderes, Franciscideres and many cyclorhagids as well as in loriciferans, taken as an outgroup. This would suggest that Pycnophyes, Kinorhynchus, Paracentrophyes, Neocentrophyes and Mixtophyes gen. nov. represent a monophyletic clade. The results of the phylogenetic analyses made by Yamasaki et al. (2013) and Dal Zotto et al. (2013) are compatible with the idea that the condition of segment 1 in Pycnophyes and Kinorhynchus, with one tergal, two episternal and a midsternal plate, also represents a derived condition. Hence, it makes sense to imagine an evolutionary character transition going from a segment 1 formed from a closed ring, as expressed in Dracoderes and Franciscideres as well as in cyclorhagids (outgroup), through differentiation into a single tergal and sternal plate, as expressed in Neocentrophyes, Mixtophyes gen. nov. and, to some extent, Paracentrophyes, and a final differentiation of the sternal plate into one midsternal and two episternal plates. If this hypothetical transition series is correct, it seems likely that the condition of the sternal plate of segment 1 in Paracentrophyes, with a partially developed subdivision of the plate represents an intermediate stage between the condition in, on the one hand, Neocentrophyes and Mixtophyes gen. nov., and, on the other hand, Pycnophyes and Kinorhynchus. This would suggest that Paracentrophyes represents the sister taxon to Pycnophyes and Kinorhynchus and that Neocentrophyes and Mixtophyes gen. nov. branch off more basally (Fig. 7a-c).

This proposed character transition is also supported by ontogeny. The postembryonic development of Pycnophyes dentatus (Reinhard, 1881), P. kielensis Zelinka, 1928 and Paracentrophyes praedictus Higgins, 1983 is known in detail. In juvenile stages of these three species, segment 1 consists of a tergal plate and a single, undivided sternal plate (Neuhaus 1993, 1995). The partial or total differentiation of the sternal plate into three is observed only in the adult stage in Pycnophyes (Neuhaus 1993), whereas in 

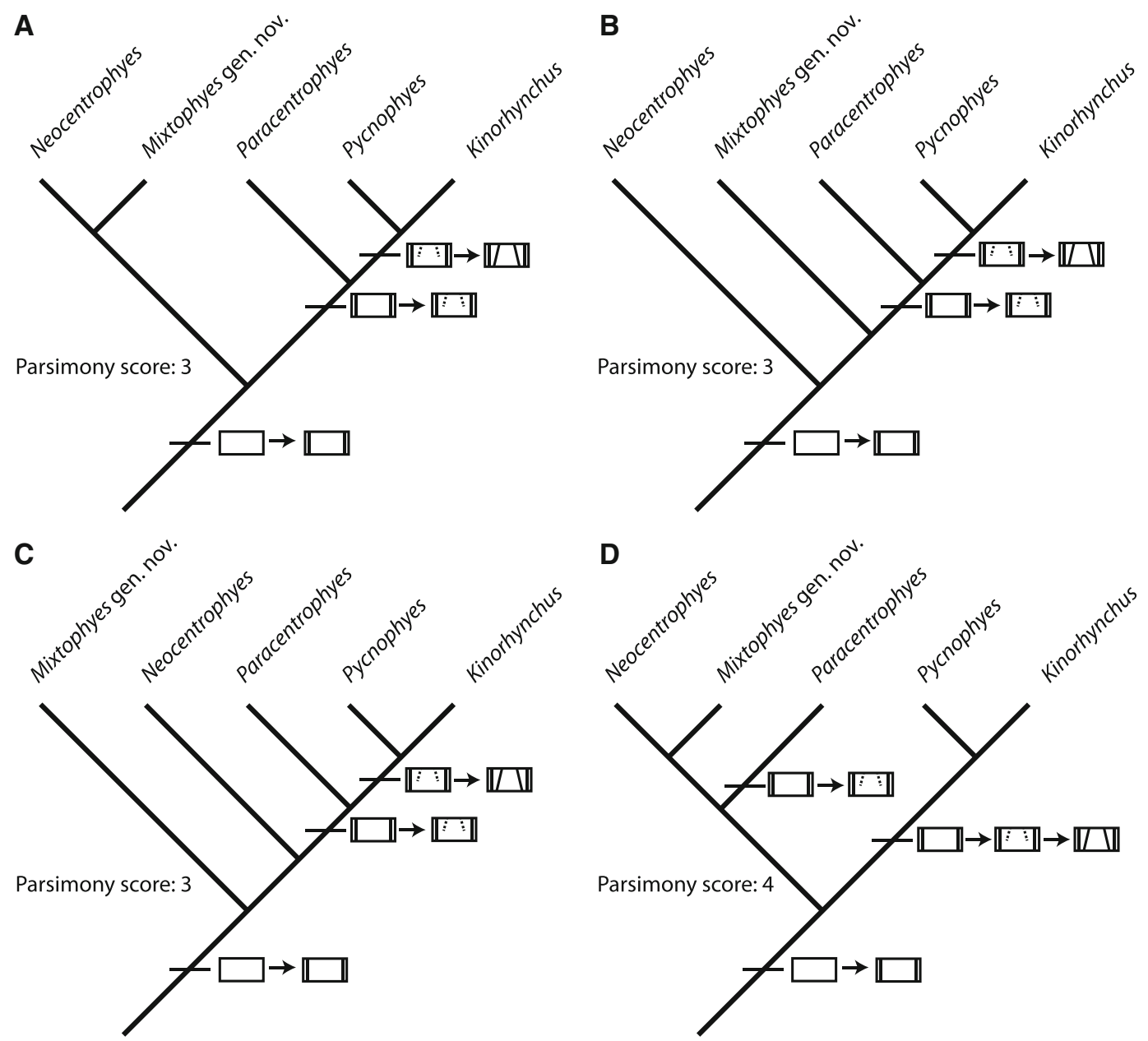

Symbols showing possible compositions of segment 1

Closed ring $\square 1$ tergal and 1 sternal plate

1 tergal and 1 partially subdivided sternal plate
1 tergal plate, and sternal

III] plate differentiated into episternal and midsternal plates
Fig. 7 Four different topologies with the evolutionary plate transformations on segment 1, optimized in three most parsimonious (ac) and one less parsimonious (d) ways. The putative transformation series goes through following stages: (1) segment composed of a closed ring (putative ground pattern), (2) segment composed of one

Paracentrophyes, it usually appears in the adult stage (Neuhaus 1995) even though it may also occur in the J-6 stage (Sánchez, pers. obs.). This also indicates that the undivided sternal plate would be plesiomorphic condition relative to the subdivided plate.

The proposed scenario seems likely, but it is somehow obscured by other two traits: the presence of lateral terminal spines and the condition of segment 11 . This segment consists of a tergal and paired sternal plates in Pycnophyes and Kinorhynchus (Zelinka 1928; Sheremetevskij 1974), and a tergal and an unpaired sternal plate in Neocentrophyes, Mixtophyes gen. nov. and Paracentrophyes (Higgins 1969, 1983; Sørensen et al. 2010; tergal and one sternal plate, (3) segment composed of one tergal plate and a partially differentiated sternal plate, (4) segment composed of one tergal plate and sternal plate differentiated into one midsternal and two episternal plates

present contribution). This character alone would agree with a monophyletic clade formed by the three latter taxa (Fig. 7d), but it would also contradict the scenario proposed above (Fig. 7a-c). It is not possible to optimize both characters on the same tree (i.e., the condition of the sternal plates on segments 1 and 11) without making at least one of them homoplastic. Under these conditions, we would consider the transformation series of segment 1 as the one that provides most significant phylogenetic information, since we know that the plate composition of segment 11 may vary, even at intrageneric levels (see Neuhaus and Blasche 2006; Sørensen et al. 2013). Lateral terminal spines are present in species of all kinorhynch genera 
except those of Kinorhynchus and Neocentrophyes (Zelinka 1928; Sheremetevskij 1974; Higgins 1969; Sørensen and Pardos 2008). However, since no other character points toward a sister-group relationship between these two genera, we would consider the loss of lateral terminal spines as two independent autapomorphic traits and therefore without phylogenetic relevance above genus level.

Conclusively, since the presence of a single, undivided sternal plate on segment 1 would represent a plesiomorphic condition within a clade with Mixtophyes gen. nov. and the four traditional homalorhagid genera, its presence in Neocentrophyes and Mixtophyes gen. nov. cannot be used as an argument to consider the two genera as closest relatives-or at least overrule other equally parsimonious alternatives. Likewise, the partial differentiation of the sternal plate on segment 1 in species of Paracentrophyes would suggest that this genus is closer to Pycnophyidae. Hence, and after disregarding plate arrangement in segment 11 and presence of lateral terminal spines as suitable characters, the plate configuration of segment 1 suggests that Mixtophyes gen. nov. is either sister taxon to Neocentrophyes (Fig. 7a), to an assemblage of Paracentrophyes, Pycnophyes, and Kinorhynchus (Fig. 7b) or to a clade with the four mentioned genera (Fig. 7c). As a consequence, the monophyly of Neocentrophyidae also has to be questioned, since the hypothetical transformation series of segment 1 suggests that Paracentrophyes is closer to Pycnophyes and Kinorhynchus. However, as phylogenetic studies on kinorhynch relationships currently are being carried out by the authors of this paper and several collaborators, we prefer to stick with the traditional classification for now and wait with eventual revisions until the results of the phylogenetic analyses are available.

Neocentrophyidae Higgins 1969—emended diagnosis

Homalorhagida with sternal plate on first trunk segment undivided or with partial divisions at the anteriormost region of the plate; remaining trunk segments with one tergal and two sternal plates, except for the terminal segment, consisting of a tergal and a single sternal plate. Articulated rigid lateral terminal spines on segment 11 present or absent; non-articulated middorsal spinose processes on segments 1-9 in both sexes; females with nonarticulated middorsal spinose process also on segment 10 or with an articulated, pointed and rigid middorsal spine instead; males always with an articulated, flexible and soft middorsal spine on segment 10; articulated middorsal spine on segment 11 in both sexes, rigid in females and flexible in males; non-articulated midlateral spinose processes on segments 1-9; processes may be absent or present on segments 10 and 11; males with one pair of long and flexible penile spines on segment 10; additional pair of similar penile spines on segment 11 present or absent; pachycycli, peg and socket joints, and apodemes (anteromesial thickenings of ventral pachycycli) absent or not well developed; seven placids: four dorsal and three ventral; fourteen trichoscalids (7 dorsal and 7 ventral) present, but trichoscalid plates absent; four short, thin, non-articulated outer oral styles and five longer articulated ones, composed of two units.

Neocentrophyes Higgins, 1969—emended diagnosis

Neocentrophyidae with sternal plate on first trunk segment undivided. Lateral terminal spines on segment 11 absent. Females with non-articulated middorsal spinose process on segment 10; males with two pairs of long and flexible penile spines, one on segment 10 and one on segment 11 .

Identification key for homalorhagid genera and species of Neocentrophyidae

The description of a new homalorhagid genus as well as the new data provided for Neocentrophyes prompted the preparation of an updated identification key for the genera of Homalorhagida. Moreover, also considering the recent description of Paracentrophyes anurus and the additional data for P. quadridentatus (Zelinka, 1928) (see Sørensen et al. 2010), an updated key to species of Paracentrophyes would be useful. Even though $N$. intermedius and $N$. satyai could represent male and female of the same species, both entities are included as two different species in the identification key until a future proper taxonomical revision.

1. Sternal region of first trunk segment completely divided into three plates. Sternal region of terminal trunk segment divided into two plates.

2. (Family: Pycnophyidae).

Sternal region of first trunk segment undivided or partially divided anteriorly. Sternal region of terminal trunk segment formed from a single plate, undivided.

3. (Family: Neocentrophyidae).

2. Lateral terminal spines present. Genus: Pycnophyes.

Lateral terminal spines absent ...Genus: Kinorhynchus.

3. Sternal plate on first trunk segment partially divided anteriorly. Lateral terminal spines on segment 11 present. Middorsal spines present on segments $10-11$ in both sexes............................. Genus: Paracentrophyes.

Sternal plate on first trunk segment undivided. Lateral terminal spines on segment 11 present or absent. Middorsal spine on segment 10 present in males only. Middorsal spine on segment 11 present in both sexes...................... 4 . 
4. No lateral terminal spines on segment $11 \ldots$ .7. Genus: Neocentrophyes.

Lateral terminal spines on segment 11 present. .Mixtophyes abyssalis gen. et sp. nov.

5. No setae on segment 10. Short lateral terminal spines (LTS/LT = 7-9 \%)..............Paracentrophyes anurus.

Presence of setae in some positions on segment $10 \ldots .$. ...6.

6. Paralateral perispinal setae on segment 1. Two pairs of ventrolateral perispinal setae on segment 1

Paracentrophyes praedictus.

Paralateral perispinal setae on segment 1 absent. Presence of a single pair of ventrolateral perispinal setae on segment 1

Paracentrophyes quadridentatus.

7. Flexible and articulated middorsal spines on segments 10 and 11. Long midterminal process and small cuticular bulbous protrusions on segment 11

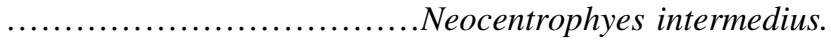

Rigid and articulated middorsal spine on segment 11 only, middorsal spinose process on segment 10. Short midterminal process and long cuticular bulbous protrusions on segment $11 \ldots . . . . . . . . . . . . . .$. Neocentrophyes satyai.

Acknowledgments We wish to thank participants of the $\mathrm{R} / \mathrm{V}$ Meteor Diva2 M63/2 Cruise and the staff and students of the Senckenberg Research Institute in Wilhelmshaven for collecting and sorting the specimens used in this study, and we also thank Dr Pedro Martínez Arbizu for making the specimens available for us. We also thank Dr Jon Norenburg, William Moser, and Kathryn Ahlfeld, Smithsonian Institution, for loaning us specimens of Neocentrophyes from the collections of the USNM. This work was supported by the Research Project CGL 2009-08928 (Ministerio de Ciencia y Tecnología, Government of Spain).

\section{References}

Adrianov AV, Malakhov VV (1994) Kinorhyncha: structure, development, phylogeny and taxonomy. Nauka Publishing, Moscow

Adrianov AV, Malakhov VV (1999) Cephalorhyncha of the World Ocean. KMK Scientific Press, Moscow

Dal Zotto M, Di Domenico M, Garraffoni A, Sørensen MV (2013) Franciscideres gen. nov.- a new, highly aberrant kinorhynch genus from Brazil, with an analysis of its phylogenetic position. Syst Biodiv 11:303-321

Herranz M, Thormar J, Benito J, Sánchez N, Pardos F (2012) Meristoderes gen. nov., a new kinorhynch genus, with the description of two new species and their implications for echinoderid phylogeny (Kinorhyncha: Cyclorhagida, Echinoderidae). Zool Anz 251:161-179

Higgins RP (1969) Indian Ocean Kinorhyncha, 2: Neocentrophyidae, a new homalorhagid family. Proc Biol Soc Wash 82:113-128

Higgins RP (1983) The Atlantic barrier reef ecosystem at Carrie Bow Cay, Belize, II: Kinorhyncha. Smithson Contrib Mar Sci 18:1-131

Higgins RP (1990) Zelinkaderidae, a new family of cyclorhagid Kinorhyncha. Smithson Contrib Zool 500:1-26
Kristensen RM, Higgins RP (1991) Chapter 10. Kinorhyncha. In: Harrison FW, Ruppert EE (eds) Microscopic anatomy of invertebrates, vol 4: aschelminthes. Wiley-Liss, New York, pp 377-404

Nebelsick M (1992) Ultrastructural investigations of three taxonomic characters in the trunk region of Echinoderes capitatus (Kinorhyncha: Cyclorhagida). Zool Scr 21:335-345

Neuhaus B (1993) Postembryonic development of Pycnophyes kielensis and P. dentatus (Kinorhyncha) from the North Sea. Microfauna Mar 8:163-193

Neuhaus B (1995) Postembryonic development of Paracentrophyes praedictus (Homalorhagida): neoteny questionable among the Kinorhyncha. Zool Scr 24:179-192

Neuhaus B (2013) Kinorhyncha (Echinodera). In: Schmidt-Rhaesa A (ed) Handbook of zoology, Gastrotricha, Cycloneuralia and Gnathifera, vol 1. Nematomorpha, Priapulida, Kinorhyncha, Loricifera. Walter de Gruyter, Berlin, pp 177-343

Neuhaus B, Blasche T (2006) Fissuroderes, a new genus of Kinorhyncha (Cyclorhagida) from the deep sea and continental shelf of New Zealand and from the continental shelf of Costa Rica. Zool Anz 245:19-52

Sánchez N, Pardos F, Herranz M, Benito J (2011) Pycnophyes dolichurus sp. nov. and P. aulacodes sp. nov. (Kinorhyncha, Homalorhagida, Pycnophyidae), two new kinorhynchs from Spain with a reevaluation of homalorhagid taxonomic characters. Helgol Mar Res 65:319-334

Sánchez N, Rho HS, Min WG, Kim D, Sørensen MV (2013) Four new species of Pycnophyes (Kinorhyncha: Homalorhagida) from Korea and the East China Sea. Sci Mar 77(2):353-380

Sánchez N, Herranz M, Benito J, Pardos F (2014) Pycnophyes almansae sp. nov. and Pycnophyes lageria sp. nov., two new homalorhagid kinorhynchs (Kinorhyncha, Homalorhagida) from the Iberian Peninsula, with special focus on introvert features. Mar Biol Res 10:17-36

Sheremetevskij AM (1974) Kinorhynchs of the Black Sea. Zool Zhurnal 53:974-987

Sørensen MV (2008) A new kinorhynch genus from the Antarctic deep sea and a new species of Cephalorhyncha from Hawaii (Kinorhyncha: Cyclorhagida: Echinoderidae). Org Div Res 8:230.e1-230.e18

Sørensen MV (2013) Phylum Kinorhyncha. Zootaxa 3703:63-66

Sørensen MV, Pardos F (2008) Kinorhynch systematics and biology an introduction to the study of kinorhynchs, inclusive identification keys to the genera. Meiofauna Mar 16:21-73

Sørensen MV, Rho HS (2009) Triodontoderes anulap gen. et sp. nov.-a new cyclorhagid kinorhynch genus and species from Micronesia. J Mar Biol Assoc UK 89:1269-1279

Sørensen MV, Thormar J (2010) Wollunquaderes majkenae gen. et sp. nov.- a new cyclorhagid kinorhynch genus and species from the Coral Sea, Australia. Mar Biodiv 40:261-275

Sørensen MV, Heiner I, Ziemer O, Neuhaus B (2007) Tubulideres seminoli gen. et sp. nov. and Zelinkaderes brightae sp. nov. (Kinorhyncha, Cyclorhagida) from Florida. Helgol Mar Res 61:247-265

Sørensen MV, Pardos F, Herranz M, Rho HS (2010) New data on the genus Paracentrophyes (Homalorhagida, Kinorhyncha), with the description of a new species from the West Pacific. Open Zool J 3:42-59

Sørensen MV, Rho HS, Min W, Kim D, Chang CY (2013) Occurrence of the newly described kinorhynch genus Meristoderes (Cyclorhagida: Echinoderidae) in Korea, with the description of four new species. Helgol Mar Res 67:291-319

Türkay M (2005) Short cruise report. RV Meteor cruise 63/2, Eastern Atlantic Ocean. RV Meteor Cruise Reports, University of Hamburg "http://www.ifm.zmaw.de/ldf/meteor-cruises/“ Accessed 16 August 2013 
Yamasaki H, Kajihara H, Mawatari SF (2012) First report of kinorhynchs from Hokkaido, Japan, including a new species of Pycnophyes (Pycnophyidae: Homalorhagida). Zootaxa 3425: 23-41
Yamasaki H, Hiruta SF, Kajihara H (2013) Molecular phylogeny of kinorhynchs. Mol Phylogenet Evol 67:303-310

Zelinka K (1928) Monographie der Echinodera. Verlag Wilhelm Engelmann, Leipzig 